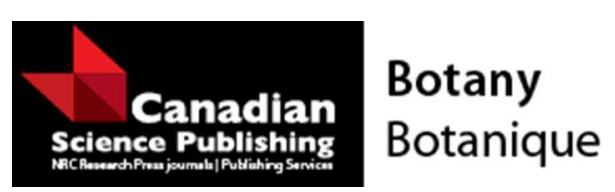

\title{
Population Decline of Endangered Lichen Erioderma pedicellatum in Nova Scotia, Canada
}

\begin{tabular}{|r|l|}
\hline Journal: & Botany \\
\hline Manuscript ID & cjb-2016-0052.R1 \\
\hline Manuscript Type: & Note \\
\hline Date Submitted by the Author: & $31-$ Mar-2016 \\
\hline Complete List of Authors: & $\begin{array}{l}\text { Cameron, Robert ; Nova Scotia Department of Environment, } \\
\text { Toms, Brad; Mersey Tobeatic Research Institute }\end{array}$ \\
\hline Keyword: & Lichen, Erioderma pedicellatum, Population Decline, Population Viability \\
\hline & \\
\hline
\end{tabular}

\section{SCHOLARONE ${ }^{\text {Tw }}$ \\ Manuscripts}


Population Decline of Endangered Lichen Erioderma pedicellatum in Nova Scotia, Canada

Robert P. Cameron

Nova Scotia Environment, P.O. Box 442, Halifax, N.S., B3J 2P8, Canada, e-mail:

Robert.Cameron@novascotia.ca, 902-237-0841 (corresponding author)

Brad Toms

Mersey Tobeatic Research Institute, 9 Mount Merritt Rd, Kempt, NS BOT 1B0, Canada, e-mail:

brad.toms@merseytobeatic.ca, 902-682-2371 


\begin{abstract}
Erioderma pedicellatum (Hue) P.M. Jørg. (1972) is a globally endangered lichen known from only four countries worldwide. The Atlantic population in Nova Scotia, Canada has been declining for at least the last several decades. The population has been closely monitored between 2003 and 2012 to determine mortality rates by life stage and population growth. A population viability model was created to assess the future viability of this population. The population declined by $12.8 \%$ over the ten year monitoring period. Mortality rates for juveniles were significantly lower than for adults. The population viability model suggests the population in Nova Scotia will decline by $49 \%$ within 25 years. Conservation measures aimed at prolonging adult survival or increasing juvenile survival is, according to the model, the best way to maintain the population.
\end{abstract}

Keywords: Erioderma pedicellatum, Lichen, Population Decline, Population Viability 


\section{Introduction}

Erioderma pedicellatum is a foliose cyanolichen in the family Pannariaceae that was first collected in Canada from Campobello Island, Charlotte County, New Brunswick, in 1902, by William Gilson Farlow. Initially it was identified as a species of Pannaria and named $P$. pedicellata Hue by the French botanist Auguste-Marie Hue (Jørgensen 2001). In 1972 the type specimen was re-examined by Per Magnus Jørgensen and transferred to the genus Erioderma. It was initially called E. Boreale (Ahti and. Jørgensen, 1971) and then E. pedicellatum (Hue) P.M. Jørg (Jørgensen 1972). It is an unusual lichen, both because of its laminal apothecia (lacking in other Erioderma species) and its boreal distribution (Jørgensen 2001).

The cyanobacterial photobiont was identified as a Scytonema sp. but is now thought to be a Rhizonema sp. (Cornejo and Sheidegger 2009). Recent molecular study suggests that all lichenized Sctonema sp. studied so far are actually a new genetically distinct lichenized genus Rhizonema (Lücking et al. 2009). The thallus of E. pedicellatum is foliose with a diameter of 2-5 $\mathrm{cm}$, occasionally reaching $12 \mathrm{~cm}$. It has a distinctively fuzzy upper surface that is greyish-brown when dry and slate-green when moist. The underside is white, and its edges usually curl upwards, giving it the appearance of having a white fringe. It differs from the two other North American species of Erioderma, E. mollissimum and E. sorediatum by having small, reddishbrown apothecia on its upper surface rather than soredia which are found in other species. It grows on the trunks and the branches of Balsam Fir (Abies balsamea (L.) Mill.), occasionally on Black Spruce (Picea mariana (Mill.) Britton, Sterns \& Poggenb.), rarely on White Spruce (Picea 
glauca (Moench) Voss) or Red Maple (Acer rubrum L.) and very rarely on White Birch (Betula papyrifera Marshall) (COSEWIC 2002, COSEWIC 2014).

Erioderma pedicellatum is now known from Eastern Canada, Norway and Alaska (Cameron et al. 2009) and possibly a population in the Kamchatka Peninsula of Siberia (Scheidegger personal communication 2013). Despite being protected, the known extant occurrence in Sweden disappeared after adjacent forestry is thought to have changed the microclimate (Purvis 2000).

The International Union for the Conservation of Nature listed the world population of $E$. pedicellatum critically endangered in 2003 (Scheidegger 2003). However, a recent discovery of a large population of $E$. pedicellatum in Denali Park, Alaska may suggest the world population is less critically endangered than initially thought (Nelson et al. 2009, Stehn et al. 2013).

In eastern Canada the Atlantic population of E. pedicellatum, known historically from New Brunswick and currently from Nova Scotia, is listed nationally and provincially as endangered while the boreal population on the Island of Newfoundland is listed as a Species of Special Concern (COSEWIC 2014). Both the Boreal and Atlantic populations have declined over the last several decades (COSEWIC, 2002, Cameron et al. 2010, Goudie et al. 2011). A 90\% decline in the number of occurrences in the Atlantic population was recorded between 1980 and 2000 (COSEWIC 2002). Several possible causes of this decline have been identified or proposed (Cameron et al. 2010, Cameron et al. 2013a, Cameron et al. 2013b), one reason being that little is known about the population ecology of this species. An understanding of the population structure, fecundity rates and survival of different growth stages would help identify the main cause of the decline and assist in conservation efforts. 
The Atlantic population E. pedicellatum has been carefully monitored since 2003 (Cameron et al. 2013a) and frequent surveys for new thalli have also been done in predicted habitat (Cameron and Neily 2008). The aim of the present study was to analyze these data to determine survival of the known population and at different growth stages and develop a population model to assess future population viability.

\section{Methods}

\section{Study Area}

The study area was the Atlantic coastal rain forest of Nova Scotia. This forest occurs along the Atlantic slope of Nova Scotia as a linear coastal band varying in width from about 30 to $60 \mathrm{~km}$ and about $500 \mathrm{~km}$ long from the southwest of the province in Shelburne County to the northeast in Cape Breton County (Clayden et al. 2011). This forest is characterized by warm winters with a mean temperature of $-4.5^{\circ} \mathrm{C}$ and cool summers with a mean temperature of $16.4^{\circ} \mathrm{C}$. Precipitation is high, generally exceeding $1400 \mathrm{~mm}$ annually in many locations. Much of the precipitation falls as rain, averaging $85 \%$ of total precipitation for many locations (Clayden et al. 2011). Fog frequency is also high in these coastal forests (Yin and Arp 1994) which are dominated by balsam fir and black spruce and coastal white spruce. The area has a large number of bog and fen wetlands as a result of the high rainfall and humidity (Davis and Browne 1996).

Field Methods 
Regular yearly searches for E. pedicellatum in Nova Scotia have been ongoing since 2003 with approximately 3329 hours in search effort being expended. The search effort was guided by geographical information system (GIS) habitat model for E. pedicellatum developed by Cameron and Neily (2008). This model helps to focus search effort on predicted habitat. The model identified 13852 predicted habitat polygons of which approximately 832 were searched for $E$. pedicellatum between 2003 and 2012. Since juvenile thalli are smaller and harder to detect than adult thalli, care was taken to search thoroughly for juveniles in good habitat. Study Sites were from Shelburne County in the southwest to Cape Breton County in the northeast, a distance of about $442 \mathrm{~km}$ (Figure 1). The mean distance between sites was about $2 \mathrm{~km}$ but the distribution was uneven with clusters in Shelburne County, Halifax County and on Cape Breton Island (Richmond and Cape Breton Counties). The survival, health and mortality of all thalli were recorded annually from the time of discovery. The sites were permanently marked by stakes, tagging trees, and recording position using a GPS. Notes were made on the height and orientation of thalli on the trees. The detailed location data ensured that thalli could be consistently re-located. Annual data recorded included size (height and width) and health of individual thalli (\% grazing and necrosis, host tree attachment). The number of return visits to each site varied, with the oldest sites visited 6 times and the most recent sites visited only once.

\section{Analyses}

Estimated survival of E. pedicellatum was done with the nonparametric Kaplan-Meier procedure (Kaplan and Meier 1958). In the Kaplan-Meier procedure the survival time is a measure of the interval between an origin and the occurrence of a given event (Lee and Go 
1997). All thalli were monitored from the time of discovery until death or the end of the monitoring period in 2012. Death was recorded when a thallus was found to be dead, or no longer visible. In this statistical treatment, left censoring, also known as staggered entry, occurs when thalli are found after the commencement of the monitoring period. Right censoring occurs when the time of death for some individuals is uncertain. Since the end of the monitoring period was 2012, the time to death of those thalli that did not die during the monitoring period was uncertain, and thus right censored the data. Cumulative survival was calculated separately for juvenile thalli and mature thalli. The log-rank test was used to determine if there was a significant difference between survival of juveniles and adults with a significance level of $p=0.05$.

The annual population change for Nova Scotia was calculated using the method described in (COSEWIC 2011). New juveniles discovered as a result of searches were considered recruits to the population. Thalli which could not be relocated or thalli with more than $90 \%$ of the surface grazed or necrotic were considered deaths. Annual rate of change at year $t$ was calculated as:

$$
A t=\left(\frac{N J t-D t}{P t}\right) 100
$$


Where $A t$ is annual rate of change of the population at end of year $t$; NJt is number of new juveniles discovered during year $t$; $D t$ is the number of deaths that occurred during year $t$ and $P t$ is the known population at the beginning of year $t$.

To examine predicted future population changes, a deterministic population viability analysis was done following methods described by Morris et al. (1999). A program written in Visual basic (VBA) was used to calculate annual growth rate $(\lambda)$. The population was divided into 3 life stage classes: 1 . Juvenile - individuals which have no reproductive structures; 2 . Adult individuals with apothecia and healthy with no signs of necrosis; 3. Loose-necrotic - adults that are loosely attached to the substrate, have reproductive structures, and at least $10 \%$ of the surface with evidence of necrosis. A projection matrix was created using survival and fecundity rates. The matrix shows transition rates from one life stage to the next (Figure 2). Fecundity values are shown in the first row and survival rates in the succeeding rows to represent transition from one stage to the next. A population vector was created which represents the number of individuals currently in each life stage arranged in a vertical column. The population is projected into the future (time step $t_{1}$ ) by multiplying the projection matrix by the population vector which results in a new population vector. The new population vector is multiplied by the projection matrix to project the population to time step $t_{2}$. The process was continued up to year $t_{25}$. After an initial population projection was created, fecundity, juvenile survival, adult survival and loose-necrotic survival were each artificially increased in separate projections until $\lambda$ was equal to 1 . This was done to determine which life stage had the most influence on $\lambda$.

\section{Results}


Three hundred and twenty-eight thalli of E. pedicellatum were found and monitored. Fifty-six of the three hundred and twenty-eight thalli died over the monitoring period. Juveniles accounted for 85 of the monitored thalli, 5 of which died during the monitoring period. Fiftyone mature thalli died. Although new thalli have been discovered every year since 2003, previously discovered thalli continued to die. Less than half the number of new juveniles $(n=$ 19) were found in comparison with the number of total thalli that died ( $n=56)$ during the monitored period.

The Kaplan-Meier survival functions for juveniles were significantly lower than for mature thalli $(p=0.02)($ Table 1$)$

The population experienced an increase in annual rate of change in 2006 and 2007 but there has been an increasing annual decline since then (Figure 3). The 10-year trend for Nova Scotia was calculated as $r=-0.1284$.

Population viability analysis suggests the current population will decrease by $49 \%$ within 25 years given a $\lambda$ of 0.98 (Figure 4 , Table 2 ). An increase of fecundity of 25.0 times the current level would be needed to bring the $\lambda$ to 1.0 , while an increase of 1.3 times the current juvenile survival would be required to achieve the same level of $\lambda$. Only a small increase $(<1.1$ times increase) in adult survival would be needed to increase $\lambda$ to 1.0 but this would be nearly $100 \%$ survival. An increase in survival to $100 \%$ of loose-necrotic would not be sufficient to increase $\lambda$ to 1.0 , likely because there are so few thalli in this life stage.

\section{Discussion}


Careful monitoring of E. pedicellatum in Nova Scotia clearly shows a declining population. The results of this study are consistent with earlier studies which documented a $90 \%$ loss of known E. pedicellatum sites in Nova Scotia between 1980 and 2000 (COSEWIC 2002). Declines have also been found for some areas of Newfoundland on the basis of frequent revisits of marked thalli (Goudie et al. 2011). There is also evidence suggesting a decline in the population of the other species of Erioderma, E. mollissimum in Canada. At least $80 \%$ of sites in Nova Scotia known from the early 1980 s no longer support $E$. mollissimum. Occupancy rates of habitat patches have declined in Nova Scotia and this species like E. pedicellatum appears to have been extirpated from New Brunswick (COSEWIC 2009). Hinds and Hinds (2007) found 9 species of cyanolichen that once occurred in New England have disappeared and consider that two of the main factors responsible for this are air pollution, and the progressive loss of old forests. Although air pollution has been decreasing in Atlantic Canada over the last two decades (CCME 2008), trans-boundary air pollution in the form of acid rain and acid fog is still affecting the environment (CCME 2013). Cyanolichens are extremely sensitive to acid rain (Richardson 1992, Richardson and Cameron 2004). Acid rain can eventually overwhelm the very limited buffering capacity of balsam fir bark which can become too acid for colonization (Nieboer et al. 1984). Acid fog is an even greater problem because droplets have an even lower $\mathrm{pH}$ and the lichens remain enveloped for extended periods (Cox et al. 1989; Kouterick et al. 1998). Thus, air pollution is likely one major factor leading to the gradual disappearance of sensitive cyanolichens from southern Nova Scotia and the Bay of Fundy regions of New Brunswick,

The loss of mature or old forest may be another main factor leading to the declines of $E$. pedicellatum in Nova Scotia. The mean age for forest stands with E.pedicellatum is 57 years 
(Cameron and Neily 2008). The trees may not be old, but the forests have a long history of forest structural continuity (Neily et al. 2004). Modelling of habitat in Nova Scotia by Cameron et al. (2013b) suggest there has been a continuing decline in available habitat, at least since 1987. This decline appears to be related to forestry. Forestry adjacent to and within the landscape where E. pedicellatum occurs has been linked to mortality of the lichen. It is likely that adjacent tree harvesting increases wind and solar radiation which leads to drying of the habitat (Cameron et al. 2013a).

Erioderma pedicellatum is at the southern extent of its range in Nova Scotia (COSEWIC 2002, Cameron et al. 2010) and recent warming trends as a result of climate change may be having an effect on survival. Furthermore, fog frequency along the Atlantic coast of Nova Scotia has declined significantly in past decades (Beauchamp et al. 1998, Muraca et al. 2001) both of which lead to drying of the habitat. Finally, grazing of E. pedicellatum by alien invasive slugs could be affecting survival of mature thalli (Cameron 2009). Of 105 E. pedicellatum thalli monitored in Nova Scotia between 2004 and 2009, 29\% showed evidence of grazing (COSEWIC 2014).

The deterministic population model from this study suggests the known population of $E$. pedicellatum in Nova Scotia will decline by $49 \%$ within 25 years. Much greater declines are reported for Newfoundland (Goudie et al. 2011) with $\lambda$ of 0.83 and 0.96 compared to 0.98 for this study. The population model for Nova Scotia suggests that improving adult or juvenile survival would be the most efficient ways to conserve the population. Similar results were found for Newfoundland with the later life stages having the greatest effect on population 
growth (Goudie et al. 2011). Goudie et al. (2011) proposed that E. pedicellatum populations in Newfoundland survived in the past as a K-selected species that had long adult survival. Recent threats to adult survival have affected the population growth rate. This may also apply to the Nova Scotia population. Some Erioderma pedicellatum sites in Nova Scotia have been occupied for 18 years (COSEWIC 2002) and in one case for 25 years (Cameron et al. 2010).

Unlike, Newfoundland, the population model for Nova Scotia also suggests that improving juvenile survival would also be an efficient way to conserve the population. Conserving juveniles presents some challenges. Juveniles are small and difficult to find. They are easily dislodged by passing squirrels or birds and a single grazing event by a large invasive gastropod could completely kill an individual. Some research will be required to determine the best way to conserve E. pedicellatum juveniles.

The recent discovery of a large population of E. pedicellatum in Denali Park, Alaska may suggest the world population in not as threatened as was initially thought (Nelson et al. 2009, Stehn et al. 2013). Indeed, this discovery increases the known world population almost tenfold. However, little is known about this population other than an estimate of the population size. For example, it is unknown if the population is stable, increasing or declining. So far there has been no molecular work to show whether or not the Alaskan population, which grows on the twigs and small branches of Picea glauca, rather than trunks of Abies balsamea, is genetically distinct from the Canadian population (COSEWIC 2014). Although the world population of $E$. pedicellatum may be less threatened, the designation of endangered status for the Atlantic population is supported by this study which suggests the population is small and declining. 
We suggest that conservation efforts should be focused on adult survival. Areas where adults are common should be even more actively protected from any effects of forestry or other developments that would alter the moist micro-climate required by this lichen. Currently on Crown land in Nova Scotia a $100 \mathrm{~m}$ no timber harvest buffer around all known sites with $E$. pedicellatum is required. Additionally, a $20 \mathrm{~m}$ no timber harvest buffer around any associated wetlands is also required (NSDNR 2012). However, these buffers are not enforced on private land which makes up almost $70 \%$ of the land area of Nova Scotia (NSDNR 2008). Further, Cameron et al. (2013b) suggests these buffers may not be adequate at all sites. More stringent practices like those suggested by Cameron et al. (2013b) are needed at adult thalli sites on both private and Crown land. Methods for conserving juveniles should also be explored. These may include ex situ rearing and transplanting in suitable habitat or in situ efforts such as large forestry buffers.

\section{Acknowledgements}

The authors would like to thank field staff Tom Neily and Chris Pepper and volunteer Harold Clapp without whose expertise and skill this study would not be possible. We would also like to thank Julie Towers for a helpful review of an earlier manuscript as well as one anonymous reviewer and David Richardson for helpful reviews of later manuscripts. Some of the information used or referenced in this document is Crown Copyright, compiled on behalf of COSEWIC under a contract with Environment Canada, however, comments or conclusions made by the author using this information do not necessarily reflect the opinions of Environment Canada or COSEWIC. Some map data for Figure 1 were reproduced with the permission of Service Nova Scotia \& Municipal Relations.

\section{References}


Ahti, T. and Jørgensen, P.M. 1971 Notes on the Lichens of Newfoundland. I. Erioderma boreale, New to North America.The Bryologist 74(3): 378-381.

Beauchamp, S., Tordon, R. and Pinette, A.. 1998. Chemistry and deposition of acidifying substances by marine advection fog in Atlantic Canada. In Proceedings: First International Conference on Fog and Fog Collection, Vancouver, Canada, July 19-24, 1998. Edited by R. S. Schemenauer and H. Bridgman. International Development Research Centre, Ottawa. pp. 171174.

Cameron, R.P. 2009. Are non-native gastropods a threat to endangered lichens? Canadian Field Naturalist 123: 169-171.

Cameron, R.P. and Neily, T. 2008. Heuristic model for predicting habitat of Erioderma pedicellatum and other rare cyanolichens in Nova Scotia, Canada. The Bryologist 111: 650-658. Cameron, R. P., C. Hanel, C., Goudie, I. and Neily, T. 2009. Erioderma pedicellatum, boreal felt lichen: current status, conservation issues and future prospects. Botanical Electronic News 420. Available from http://www.ou.edu/cas/botany-micro/ben/ben420.html

Cameron, R.P., Neily, T. and Anderson, F. 2010. Observations of mortality in a small population of the endangered lichen Erioderma pedicellatum. Opuscula Philolichenum 8: 67-70. Available from http://sweetgum.nybg.org/philolichenum/ 
Cameron, R.P., Neily, T. and Clapp, H. 2013a. Forest harvesting impacts on mortality of an endangered lichen at the landscape and stand scales. Canadian Journal of Forest Research 43: 507-511.

Cameron, R.P., Goudie, I. and Richardson, D.H.S. 2013b. Habitat loss exceeds habitat regeneration for and IUCN flagship lichen epiphyte: Erioderma pedicellatum. Canadian Journal of Forest Research 43: 1075-1080.

CCME 2008. A national picture of acid deposition critical loads for forest soils in Canada. Canadian Council of Ministers of the Environment. Available from http://www.ccme.ca/files/Resources/air/acid_rain/national_picture_acid_deposition_pn1412. pdf

CCME 2013. Progress report on the Canada-wide acid rain strategy for post-2000. PN 1490. Available from http://www.ccme.ca/files/Resources/air/acid_rain/pn_1490_ar_2010_2011_prgrs_rpt_1.0_e.p df

Cornejo, C. and Shiedegger, C. 2009. Does photobiont availability limit the spread of the critically endangered lichen Erioderma pedicellatum? Poster presented at ECCB 2009.

COSEWIC 2002. Assessment and status report on the boreal felt lichen (Erioderma Pedicellatum) in Canada. Committee on the Status of Endangered Wildlife in Canada (COSEWIC), Ottawa, Ontario. Available from http://www.env.gov.nl.ca/env/wildlife/endangeredspecies/sr_boreal_felt_lichen_e.pdf. 
COSEWIC. 2009. COSEWIC assessment and status report on the Vole Ears Erioderma mollissimum in Canada. Committee on the Status of Endangered Wildlife in Canada, Ottawa. Available from http://www.registrelepsararegistry.gc.ca/virtual_sara/files/cosewic/sr_Vole\%20Ears_0810_e1.pdf

COSEWIC. 2011. Instructions for the Preparation of COSEWIC Status Reports. Committee on the Status of Endangered Wildlife in Canada (COSEWIC), Ottawa.

COSEWIC. 2014. COSEWIC Assessment and Status Report on Boreal Felt Lichen Erioderma pedicellatum in Canada. Committee on the Status of Endangered Wildlife in Canada. Ottawa. Cox, R.M., Spavold-Tims, J. and Hughes, R.N. 1989. Acid Fog and Ozone: Their Possible Role in Birch Deterioration around the Bay of Fundy, Canada. Water, Air, and Soil Pollution 48: 263276.

Davis, D. and S. Browne. 1996. Natural History of Nova Scotia. Nova Scotia Museum of Natural History and Nimbus Publishing, Halifax, NS.

Farmer, A.M., Bates, J.F. and Bell, J.N.B. 1992. Chapter 11 Ecophysiological Effects of Acid Rain on Bryophytes and Lichens. In Bryophytes and Lichens in a Changing Environment. Edited by W. Bates and A.M. Farmer. J. Clarendon Press, Oxford. pp. 284-313.

Goudie, R. I, Scheidegger, C., Hanel, C., Munier, A., and Conway, E. 2011. New population models help explain declines in the globally rare boreal felt lichen Erioderma pedicellatum in Newfoundland. Endangered Species Research 13: 181-189.

Hinds, J.W. and Hinds, P.L. 2007. The Macrolichens of New England. New York Botanical Press, NewYork. 
James, P.W. 1973. The Effects of air pollutants, other than hydrogen fluoride and sulphur dioxide on lichens. In, Air Pollution and Lichens. Edited by B.W. Ferry, M.S. Baddeley and D. Hawkesworth. Athlone Press of the University of London, London. pp. 143-175.

Jørgensen, Per M. 1972. Erioderma pedicellatum new combination equals Erioderma boreale in New Brunswick Canada. Bryologist 75: 369-71.

Jørgensen, Per M. 2001. The present status of the names applicable to species and infraspecific taxa of Erioderma (lichenised Ascomycetes) included in Zahlbruckner's "Catalogus". Taxon 50: 525-541.

Kaplan, E.L. and P. Meier. 1958. Nonparametric Estimation from Incomplete Observations. Journals of the American Statistical Association 53: 457-481.

Kouterick, K. B., Skelly, J.M., Pennypacker, S.P. and Cox, R.M. 1998. Acidic fog and Septoria betulae Pass. Impacts on two birch species along the Bay of Fundy, Canada. Conference on Fog and Fog Collection. Vancouver, Canada, 19-24 July 1998.

Lee, E. T., and Go, O.T. 1997. Survival analysis in public health research. Annual Review of Public Health 18: 105-134.

Lücking, R., Lawrey, J.D., Sikaroodi, M., Gillevet, P.M., Chaves, J.L., Sipman, H.J.M and Bungartz, F. 2009. Do lichens domesticate photobionts like farmers domesticate crops? Evidence from a previously unrecognized lineage of filamentous cyanobacteria. American Journal of Botany 96(8): 1409-1418. 
Morris, W., Doak, D., Groom, M., Kareiva, P., Fieber, J., Gerber, L., Murphy, P. and Thomson, D. 1999. A Practical Handbook for Population Viability Analysis. The Nature Conservancy. Available from https://www.agroparistech.fr/IMG/pdf/PVAHandBook.pdf

Muraca, G., Maclver, D.C, Urquizo, N. and Auld, H. 2001. The climatology of fog in Canada. In Proceedings: First International Conference on Fog and Fog Collection, Vancouver, Canada, July 19-24, 1998. Edited by R. S. Schemenauer and H. Bridgman. International Development Research Centre, Ottawa. pp. 513-516.

Neily, P., McCurdy, D., Stewart, B. and Quigley, E. 2004. Coastal forest communities of the Nova Scotian Eastern Shore ecodistrict. Nova Scotia Department of Natural Resources Report FOR 2004-4. Nova Scotia Department of Natural Resources, Halifax.

Nelson, P., Walton, J., and Roland, C. 2009. Erioderma pedicellatum (Hue) P.M.Jorg., new to the United States and Western North America, Discovered in Denali National Park and Preserve and Denali State Park, Alaska. Evansia 25: 19-23.

Nieboer, E., McFarlane, J.D. and Richardson, D.H.S.. 1984. Modification of plant cell buffering capacities by gaseous air pollutants. In Gaseous Air Pollutants and Plant Metabolites. Edited by Koziol, M., and F.R. Whatley. Butterworths, London. pp. 313-333.

Purvis, W. 2000. Lichens. Smithsonian Institution Press and London Natural History Museum, London and Washington. 
Nova Scotia Department of Natural Resources (NSDNR). 2008. State of the Forests Report.

Province of Nova Scotia, Halifax. Available from

https://www.novascotia.ca/natr/forestry/reports/State-Of-Forest-Report-April-2008.pdf

Nova Scotia Department of Natural Resources (NSDNR). 2012. Endangered Boreal Felt Lichen

Special Management Practices. NSDNR, Halifax. Available from

http://novascotia.ca/natr/wildlife/habitats/terrestrial/pdf/SMP_Boreal_Felt_Lichen.pdf

Richardson, D.H.S. 1992. Pollution Monitoring with Lichens. Richmond Publishing, Slough, UK.

Richardson, D.H.S. and Cameron, R.P. 2004. Cyanolichens: their response to pollution and possible management strategies for their conservation in northeastern North America.

Northeastern Naturalist 11: 1-22.

Clayden, S.R., Cameron, R.P. and McCarthy, J.W. 2011. Chapter 4 Perhumid Coastal and Montane Forests of Eastern Canada. In Temperate and Boreal Rain Forests of the World. Edited by D. DellaSalla. Island Press, Washington, Covelo, London.

Scheidegger, C. 2003. Erioderma pedicellatum. The IUCN Red List of Threatened Species 2003:

e.T43995A10839336. http://dx.doi.org/10.2305/IUCN.UK.2003.RLTS.T43995A10839336.en. Accessed on 31 December 2015.

Stehn, S,E., Nelson, P.R., Roland, C.A., and Jones, J.R. 2013. Patterns in the occupancy and abundance of the globally rare lichens Erioderma pedicellatum in Delali National Park and Preserve, Alaska. Bryologist 116:1-14. 
Yin, X. and Arp, P.A.. 1994. Fog contributions to the water budget of forested watersheds in the Canadian Maritime Provinces: a generalized algorithm for low elevations. Atmosphere Ocean

32: 553-566. 
Table 1. Probability of survival of Erioderma pedicellatum adult and juveniles in Nova Scotia, Canada between 2003 and 2012.

\begin{tabular}{|c|c|c|c|c|}
\hline Time (years) & Probability of Adult & $95 \% \mathrm{Cl}$ & Probability of & $95 \% \mathrm{Cl}$ \\
\hline & Survival & & Juvenile Survival & \\
\hline $0-1$ & 1 & $1-1$ & 1 & $1-1$ \\
\hline $1-2$ & 0.9 & $0.88-0.94$ & 0.8 & $0.63-0.99$ \\
\hline $2-3$ & 0.62 & $0.56-0.69$ & 0.25 & $0.14-0.57$ \\
\hline $3-4$ & 0.38 & $0.34-0.45$ & 0.12 & $0.04-0.48$ \\
\hline $4-5$ & 0.35 & $0.3-0.43$ & & \\
\hline $5-6$ & 0.17 & $0.08-0.34$ & & \\
\hline
\end{tabular}


Table 2. Population matrix for Erioderma pedicellatum in Nova Scotia, Canada with transition rates and population vector $\left(n_{t}\right)$ for each life stage.

\begin{tabular}{|l|c|c|c|}
\hline & Juveniles & Adults & $\begin{array}{c}\text { Loose- } \\
\text { necrotic }\end{array}$ \\
\hline Juveniles & 0.7619 & 0.0035 & 0 \\
\hline Adults & 0.04464 & 0.9839 & 0 \\
\hline Loose- & 0 & 0.007335 & 0.5333 \\
necrotic & & & \\
\hline
\end{tabular}

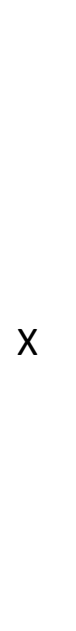

\begin{tabular}{|c|}
\hline $\mathrm{n}_{\mathrm{t}}$ \\
\hline 80 \\
\hline 177 \\
\hline 15 \\
\hline
\end{tabular}

\begin{tabular}{|c|}
\hline $\mathrm{n}_{\mathrm{t}+1}$ \\
\hline 62 \\
\hline 178 \\
\hline 9 \\
\hline
\end{tabular}


Figure 1. Known locations of Erioderma pedicellatum in Nova Scotia between 2003 and 2012. Map data (C) 2006 Province of Nova Scotia.

Figure 2. Projection matrix which shows transition rate (a) from one life stage $(j, a, l)$ to the next and population vector $\left(n_{t}\right)$ which shows population size within each life stage at time $t$. The projection matrix is multiplied by the population vector which provides population of each life stage at time $\mathrm{t}=1$.

Figure 3. Annual population change of Erioderma pedicellatum from 2003 to 2012 in Nova Scotia, Canada.

Figure 4. Projected population of Erioderma pedicellatum for 25 years from deterministic population model assuming historic population growth rates measured from 2003 to 2012 in Nova Scotia, Canada. 


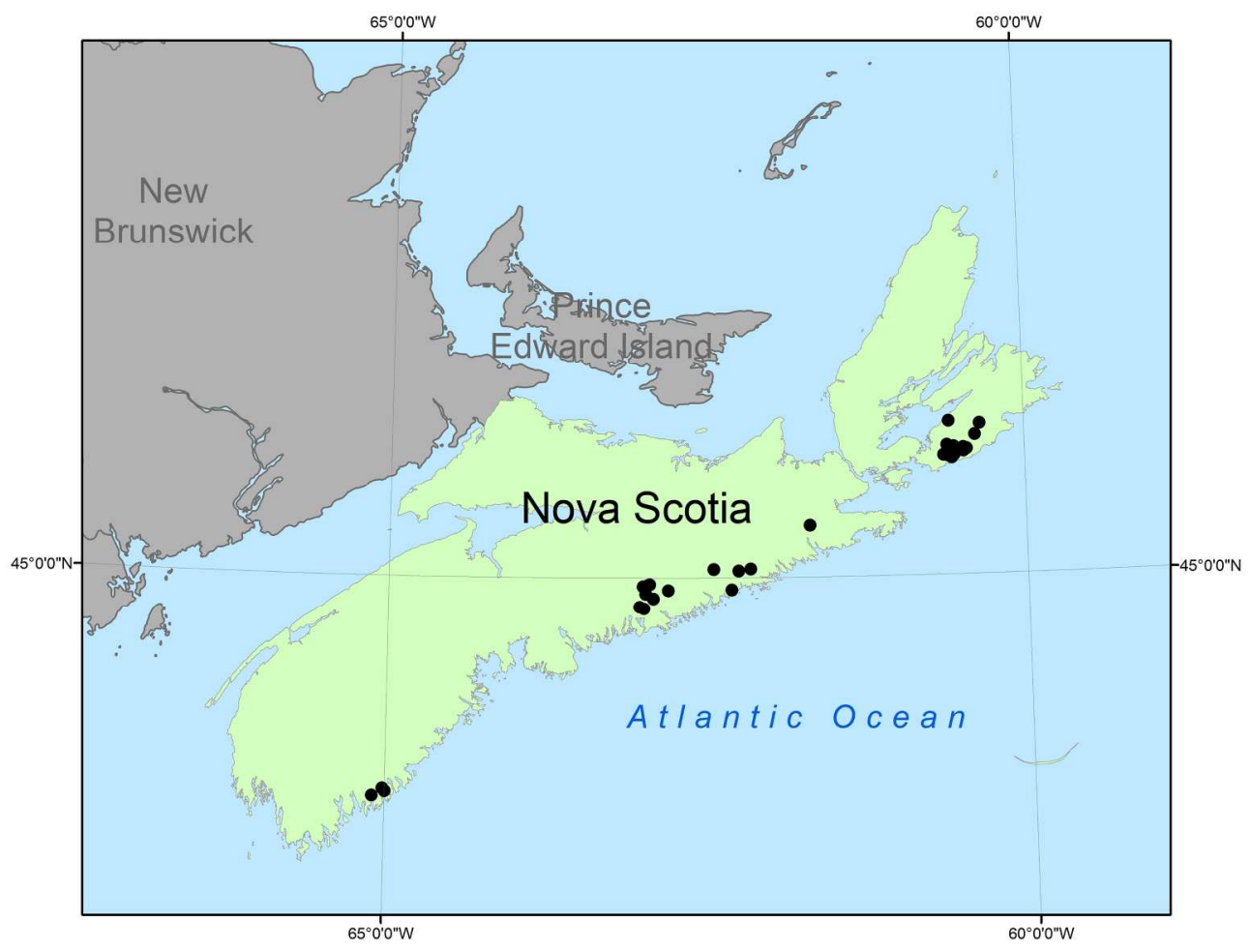

Figure 1. Known locations of Erioderma pedicellatum in Nova Scotia between 2003 and 2012. Map data (c) 2006 Province of Nova Scotia.

$215 \times 166 \mathrm{~mm}(300 \times 300 \mathrm{DPI})$ 


\begin{tabular}{|l|c|c|c|}
\hline & Juveniles & Adults & $\begin{array}{c}\text { Loose- } \\
\text { necrotic }\end{array}$ \\
\hline Juveniles & $\mathrm{a}_{\mathrm{jj}}$ & $\mathrm{a}_{\mathrm{ja}}$ & $\mathrm{a}_{\mathrm{jl}}$ \\
\hline Adults & $\mathrm{a}_{\mathrm{aj}}$ & $\mathrm{a}_{\mathrm{aa}}$ & $\mathrm{a}_{\mathrm{al}}$ \\
\hline Loose- & $\mathrm{a}_{\mathrm{lj}}$ & $\mathrm{a}_{\mathrm{la}}$ & $\mathrm{a}_{\|}$ \\
necrotic & & & \\
\hline
\end{tabular}

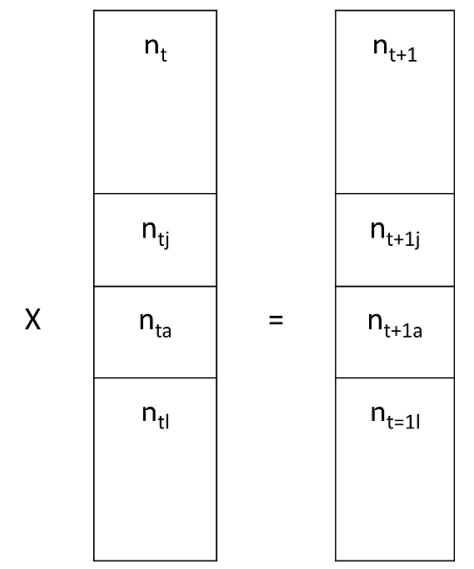

Figure 2. Projection matrix which shows transition rate (a) from one life stage $(j, a, l)$ to the next and population vector $(\mathrm{nt})$ which shows population size within each life stage at time $t$. The projection matrix is multiplied by the population vector which provides population of each life stage at time $t=1$. $338 \times 190 \mathrm{~mm}(300 \times 300 \mathrm{DPI})$ 


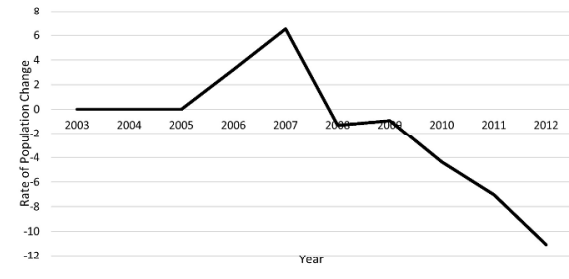

Figure 3. Annual population change of Erioderma pedicellatum from 2003 to 2012 in Nova Scotia, Canada. $338 \times 190 \mathrm{~mm}(300 \times 300 \mathrm{DPI})$ 


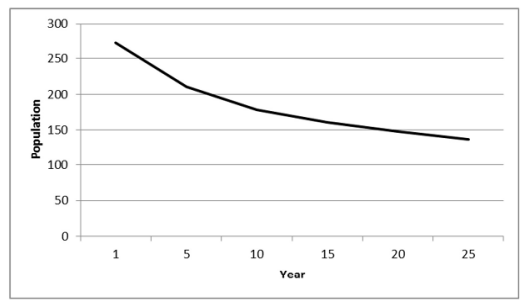

Figure 4. Projected population of Erioderma pedicellatum for 25 years from deterministic population model assuming historic population growth rates measured from 2003 to 2012 in Nova Scotia, Canada. $338 \times 190 \mathrm{~mm}(300 \times 300 \mathrm{DPI})$ 